Article

\title{
A Through-Life Cost Analysis Model to Support Investment Decision-Making in Concentrated Solar Power Projects
}

\author{
Mahmood Shafiee ${ }^{1,2}, *$, Adel Alghamdi ${ }^{2}$, Chris Sansom ${ }^{2}$, Phil Hart $^{2}$ and \\ Adriana Encinas-Oropesa ${ }^{3}$ \\ 1 School of Engineering and Digital Arts, University of Kent, Canterbury CT2 7NT, UK \\ 2 Department of Energy and Power, Cranfield University, Bedfordshire MK43 0AL, UK; \\ adel.alghamdi@cranfield.ac.uk (A.A.); c.l.sansom@cranfield.ac.uk (C.S.); P.R.Hart@cranfield.ac.uk (P.H.) \\ 3 Centre for Competitive Creative Design, Cranfield University, Bedfordshire MK43 0AL, UK; \\ a.encinas-oropesa@cranfield.ac.uk \\ * Correspondence: m.shafiee@kent.ac.uk
}

Received: 15 July 2019; Accepted: 20 March 2020; Published: 27 March 2020

\begin{abstract}
This research paper aims to propose a through-life cost analysis model for estimating the profitability of renewable concentrated solar power (CSP) technologies. The financial outputs of the model include net present value (NPV) and benefit-cost ratio (BCR) of the project, internal rate of return (IRR) and discounted payback period (DPBP) of the investment, and levelized cost of energy (LCoE) from the CSP technology. The meteorological data for a specific location in the city of Tucson in Arizona is collected from a network of automated weather stations, and the NREL System Advisor Model (SAM) is applied to simulate hourly energy output of the CSP plant. An Excel spreadsheet tool is designed to calculate, in a bottom-up approach, the financial metrics required for approval of CSP projects. The model is tested on a $50 \mathrm{MW}$ parabolic trough CSP plant and the results show an annual energy production of $456,351,232 \mathrm{kWh}, \mathrm{NPV}$ of over $\$ 64$ million and LCoE of $0.16 \$ / \mathrm{kWh}$. Finally, a sensitivity analysis is performed to identify the factors which have the most significant effect on the economic performance of CSP technologies. The proposed model can provide valuable guidance to support the strategic planning and investment decision-making in CSP projects.
\end{abstract}

Keywords: concentrated solar power (CSP); through-life cost analysis; system advisor model (SAM); net present value (NPV); benefit-cost ratio (BCR); internal rate of return (IRR); discounted payback period (DPBP); levelized cost of energy (LCoE)

\section{Introduction}

With the growing global population and escalating industrialization and urbanization, the dependence on finite and non-renewable energy resources has resulted in a number of economic, social, and environmental problems. Producing energy from renewable sources such as wind, waves, sunlight, geothermal, hydro, and biomass is an alternative to reduce society's dependence on non-renewable energy sources. Solar energy is the most abundant source of renewable energy in the world. It refers to the conversion of the sun's rays into useful forms of energy, such as electricity or heat. Though solar energy currently accounts for less than $2 \%$ of electricity generated worldwide, it is now the fastest growing renewable energy sector. According to the International Energy Agency (IEA) reports, it is anticipated approximately $22 \%$ of the world's electricity will be supplied from solar energy by 2050 [1].

Two types of technologies are often used for harnessing solar energy. These include Photovoltaic (PV) and thermal solar [2]. The PV systems convert photons from sunlight directly into electricity using semiconductor materials, whereas thermal systems convert the energy of sunlight into heat 
which can be used for producing electricity. With thermal solar, the heat from the sun is received by a number of curved mirrors called collectors that reflect the sunlight to a fluid inside the pipes. The resultant hot fluid transfers the heat to water to produce steam. This thermodynamic cycle is ended by a steam turbine connected to a conventional generator to produce the required electricity.

Concentrated solar power (CSP) is a type of solar thermal energy used to produce electricity by concentrating solar energy in a single focal point. There are currently four main types of CSP technologies in use. These include parabolic trough, power tower, parabolic dish and linear Fresnel reflectors (LFRs) [3]. The basic concept of these four technologies are shown in Figure 1. The parabolic trough is the most mature technology available on the market because it offers the potential to dispatch electricity without fossil fuel backup.

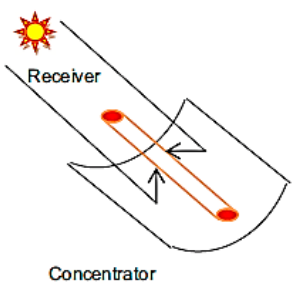

(a)

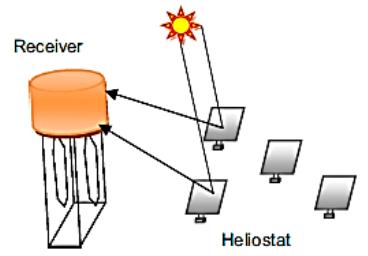

(b)

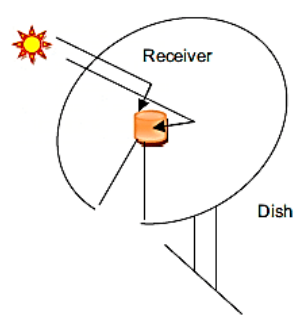

(c)

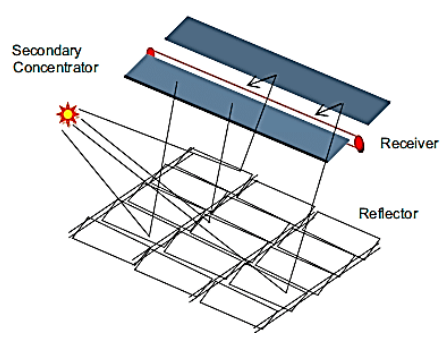

(d)

Figure 1. Four common types of concentrated solar power (CSP) technologies: (a) parabolic trough, (b) power tower, (c) parabolic dish, and (d) linear Fresnel reflectors (adapted from [4]).

Analyzing the cost implications of CSP projects with different system configuration design and climatic conditions using well-established financial models is essential for stakeholders, investors and decision-makers. Financial models usually present all cash flows occurring over the entire life of a project, from planning through design, construction, operation, and maintenance. These cash flow information can be used to estimate the profitability of investment projects on the basis of standard indexes such as net present value (NPV), benefit-cost ratio (BCR), internal rate of return (IRR), discounted payback period (DPBP), and profit index (PI) [5]. For renewable energy projects or technologies, there is another important economic index known as levelized cost of electricity (LCoE) which represents the present value of the unit cost of electricity over the lifetime of the system [6]. Accurate estimation of this metric can provide valuable information to renewable energy developers in relation to their investment decisions and help them compare different technology options in terms of cost of energy produced.

Life-cycle cost analysis (LCCA) is one of the most effective financial planning methods which was first developed by the U.S. military in the 1970s [7]. The method was later used in other sectors such as construction, energy, transport, telecommunication, healthcare, etc. to assist investors in measuring and managing the costs of a project or technology development. The LCCA process involves summing all the discounted cash flows incurred over the entire life span of a project or a technology [8]. Dale [9] performed a meta-analysis to assess the overnight capital cost, operating costs and LCoE of CSP technologies and compared the results with those of PV technologies. Mahlangu and Thopil [10] presented an LCCA approach to evaluate the external costs associated with a $100 \mathrm{MW}$ parabolic trough CSP plant located in the Northern Cape region in South Africa. Zhao et al. [11] proposed a mathematical model to calculate the LCoE from CSP projects using a lifetime cost structure analysis. Yang et al. [12] evaluated the static payback period, NPV, and IRR to analyze and discuss the costs and benefits of CSP plants in China.

Even though the LCCA process is straightforward, the cost analysis of CSP projects or technologies is a challenging task due to uncertainties arising from various sources such as intrinsic system properties, changing environmental conditions and variability of weather in different seasons of the year. Generally, weather conditions affect the amount of solar radiation received by a surface that is perpendicular to 
the sun direction — which is measured by the Direct Normal Irradiance (DNI) [13]—and, thus, can have a significant impact on financial performance of CSP plants. This study aims to present a through-life cost analysis model for evaluating the financial performance of CSP plants in terms of NPV and BCR of the project, IRR and DPBP of the investment and LCoE. The meteorological data for a specific location with high DNI (the city of Tucson in Arizona) is collected from a network of automated weather stations. The energy output of the CSP plant is estimated using a simulation model called System Advisor Model (SAM). This model uses algorithms which were developed by the National Renewable Energy Laboratory (NREL), Sandia National Laboratory (SNL) and Wisconsin University to simulate the hourly electricity output from CSP plants based on design inputs and hourly weather data. An Excel spreadsheet tool consisting of four modules, namely, input, calculations, output and charts, and sensitivity analysis is provided for bottom-up calculation of the financial metrics required for approval of CSP projects. Finally, a sensitivity analysis is performed to identify the factors which have the most significant effect on the economic performance of CSP technologies. The proposed model can provide valuable guidance to support strategic planning and investment decision-making in the CSP sector.

The paper is organized as follows. Section 2 presents a brief overview of financial analysis terms and metrics so as to set the background for the main contribution of the paper. Section 3 describes the components of our through-life cost analysis model in detail and formulates the corresponding equations. In Section 4, the implementation of the proposed model on a case study is presented, and in Section 5, the results are discussed. Finally, the paper is concluded in Section 6.

\section{Research Background}

\subsection{Financial Analysis Terminologies}

In financial analyses, there are some common terminologies used to describe the economic performance of a project. These terminologies are briefly explained in this Section.

Cash flow: The cash flows of a project usually arise from three activities: operating, investing, and financing activities. The operating cash flows refer to all revenues from production minus the expenses associated with operation and maintenance (O\&M), interest and income taxes, etc. Investing cash flows include the capital cost of a project, whereas financing cash flows include the money received as debt or equity such as bank loans, capital contributions from shareholders, etc. [14].

Present value: It is the current value of a stream of future cash flows, which can be calculated by discounting each of the cash flows to the present [15].

Discount rate: It represents the rate at which all future cash flows are converted to a present value. There are two types of discount rates: "real" and "nominal". The real discount rate contains the effect of inflation, whereas the nominal discount rate does not consider the effect of inflation [16].

Capital cost: It includes cost of purchasing the plant, construction, buildings, and all costs needed to operate a project.

Taxes: It is additional money charged by the government to businesses. All taxes during the lifetime of a project must be added to the total cost.

Tax credit: It is a reduction in income taxes that owed to the government. The value of tax credit depends on the nature of the project. The tax credit usually applies to particular costs and not to the total project cost.

Depreciation: It is defined as a reduction in the value of an asset with the passage of time, due in particular to wear and tear, technological outdating or obsolescence, etc. It is known as a means of recovering, through an income tax deduction, the cost of property used in a trade or business or of property held for the production of income [14]. 


\subsection{Financial Metrics for CSP Projects}

The objective of a financial analysis is to determine whether or not a project is financially viable and beneficial from the perspective of the project owner. The financial performance of a CSP project or technology can be characterized by a number of metrics as explained below:

Net Present Value (NPV): NPV is defined as the sum of present values of all future cash flows generated by a project after accounting for the initial capital investment. Let $\mathrm{CF}_{n}$ denote the cash flows in year $n(=1,2, \ldots, \mathrm{N})$, where $\mathrm{N}$ is the lifetime of the project. Then, the NPV can be calculated by the following equation [17]:

$$
\mathrm{NPV}=\mathrm{IIC}+\sum_{n=1}^{\mathrm{N}} \frac{\mathrm{CF}_{n}}{(1+\mathrm{NDR})^{n}}
$$

where IIC represents the initial investment cost and NDR is the nominal discount rate.

Total Life Cycle Cost (TLCC): TLCC is the sum of the initial capital investment and the yearly net present value costs accrued during the lifetime of a project or a technology. Thus, the TLCC is calculated by the following equation:

$$
\mathrm{TLCC}=\mathrm{IIC}+\sum_{n=1}^{\mathrm{N}} \frac{\mathrm{AC}_{n}}{(1+\mathrm{NDR})^{n}}
$$

where $\mathrm{AC}_{n}$ represents the project's costs in year $n(=1,2, \ldots, \mathrm{N})$.

Internal Rate of Return (IRR): It is a discount rate that makes the NPV of all cash flows from a project equal to zero. This metric is useful to evaluate the attractiveness of a project and compare the profitability of an investment with other potential investments. IRR can be calculated by solving a polynomial equation given by:

$$
\mathrm{IIC}+\sum_{n=1}^{\mathrm{N}} \frac{\mathrm{CF}_{n}}{(1+\mathrm{IRR})^{n}}=0 .
$$

Discounted Payback Period (DPBP): DPBP is the length of time that it takes to recover the initial capital investment after taking into consideration the time value of money. DPBP can be calculated by the following equation [18]:

$$
\mathrm{DPBP}=\ln \left(\frac{1}{1-\frac{\mathrm{IC} \times \mathrm{NDR}}{\mathrm{CF}_{n}}}\right) \div \ln (1+\mathrm{NDR}) .
$$

Benefit-Cost Ratio (BCR): BCR is a financial metric used to determine whether and to what extent the benefits of a project outweigh its costs. This ratio is defined as the total present value of benefits divided by the total present value of costs. Therefore,

$$
\mathrm{BCR}=\frac{\sum_{n=1}^{\mathrm{N}} \frac{\mathrm{AB}_{n}}{(1+\mathrm{NDR})^{n}}}{\mathrm{TLCC}},
$$

where $\mathrm{AB}_{n}$ represents the project's benefits in year $n(=1,2, \ldots, \mathrm{N})$, and TLCC is given by Equation (2). In theory, any project with BCR greater than one is considered to be economically viable. A BCR less than one indicates that the costs are greater than the benefits, and therefore the project will not be economically feasible. The BCR can also be used as a criterion for ranking investment projects with positive net benefits, where a larger benefit-cost ratio is given higher priority.

Levelized Cost of Energy (LCoE): This is a very popular financial metric which is used for comparing the cost of energy generated by different renewable energy sources/technologies. LCoE is defined as the sum of net present values of all expenditures over the lifetime of a CSP plant divided by the total generated energy. LCoE may vary from one project to another, depending on the size of project, the location's DNI level, the adopted CSP technology, capital and operating costs, etc. The equation for LCoE is given in Equation (6): 


$$
\mathrm{LCoE}=\frac{\mathrm{TLCC}}{\sum_{n=1}^{\mathrm{N}} \frac{\mathrm{OE}_{n}}{(1+\mathrm{NDR})^{n}}}
$$

where $\mathrm{OE}_{n}$ represents the energy output in year $n(=1,2, \ldots, \mathrm{N})$ and TLCC is given by Equation (2).

\section{Proposed Methodology}

There are different types of financial models that can be adopted to estimate the costs/benefits associated with renewable energy generation. The LCCA is the most preferred method for estimating cash flows associated with a project or technology. This is because LCCA has the capability to take into account after-tax cash flows as well as the incentives. There are two main approaches to use for LCCA calculations, namely, top-down and bottom-up. The top-down cost estimation starts with gathering data, followed by formulating the assumptions and deriving the cost relationships, and it ends with applying those to derive cost estimates for the project [19]. Generally, the top-down cost estimates are held at higher levels and are therefore often inaccurate. To overcome this problem, the bottom-up approach is recommended in which the cost analysis begins from the lowest level (child level) and is followed by aggregating the estimated cost of the child elements to obtain the cost of the parent element, which finally leads to estimation of the project's total cost [20].

In this study, a discounted cash flow (DCF) model is developed to evaluate the economic performance of CSP projects and technologies over their entire lifetime. Our model takes into consideration all factors that are important in renewable energy investment decision-making, including the energy output, capital cost, operating costs and the time value of money. Since our through-life cost analysis model involves also the estimated energy output from CSP plants, the bottom-up approach will be used for the evaluations. Figure 2 depicts the bottom-up through-life cost analysis tool developed in this paper to support CSP investment decision-making. As can be seen, our tool consists of five modules:

I) definition of input data, system boundaries and model assumptions;

II) simulation of annual energy output;

III) estimation of project's total costs;

IV) estimation of annual cash flows; and

V) calculation of financial metrics.

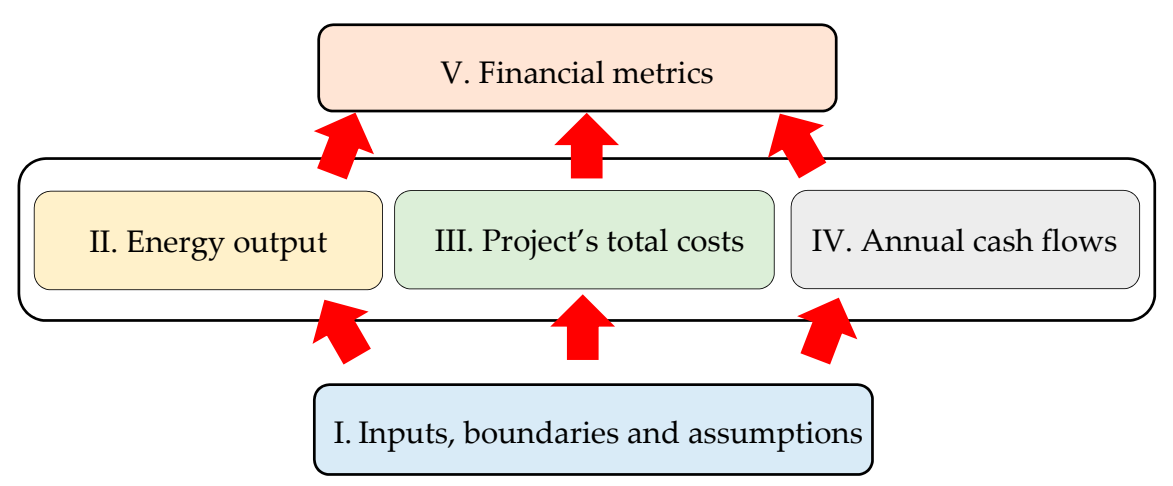

Figure 2. Five modules of the proposed bottom-up through-life cost analysis tool for CSP plants.

In what follows, the five modules of our tool are described and their corresponding cost functions are presented.

\subsection{Definition of Input Data, System Boundaries and Model Assumptions}

Our through-life cost analysis model is built based on the assumption that the investment is owned by a single owner. Generally, an entity that enters into a single owner structure receives all of the 
cash and tax benefits from the project. The investor often creates a special purpose entity-sometimes referred to as a special purpose vehicle (SPV)—for the project assets and pays the project's capital costs with funds from other operations. However, the project cash flows, tax incentives, and depreciation benefits remain with the owner. This structure is generally used for renewable energy projects as it represents one of the simplest methods of owning and operating a project [21]. Other assumptions that are taken into account when building the model are listed below:

- $\quad$ No incentives are considered for this business.

- $\quad$ Power purchase agreement (PPA) price and time of delivery (TOD) factors are constant throughout the project period, with a yearly $1 \%$ escalation in the price.

More so, the current market conditions within which the CSP plant is intended to operate are identified and the scope and boundaries of the project are defined.

\subsection{Simulation of The Annual Energy Output}

The annual energy output of the CSP plant is estimated using a simulation tool called System Advisor Model (SAM). SAM is a user-friendly, open-source platform which was developed by the NREL of the U.S. Department of Energy, to help project stakeholders assess both energy production as well as economic performance of renewable energy technologies including solar PV and CSP. This model can run simulations to calculate the hourly electricity output of CSP plants according to their design characteristics and surrounding environments [22]. SAM has an up-to-date meteorological data library for different locations around the world. When the desired location is chosen, the model will take the weather data from its library and then applies it directly to simulate the energy output. In addition to weather data, the SAM requires further input data about the CSP plant (e.g. its capacity and generation constraints); however, the tool itself has some pre-set default input values which can be used in cases where there is lack of information. After entering the required data into the model, the output performance metrics will be calculated and shown in the result page. Figure 3 depicts the interface of SAM simulation software.

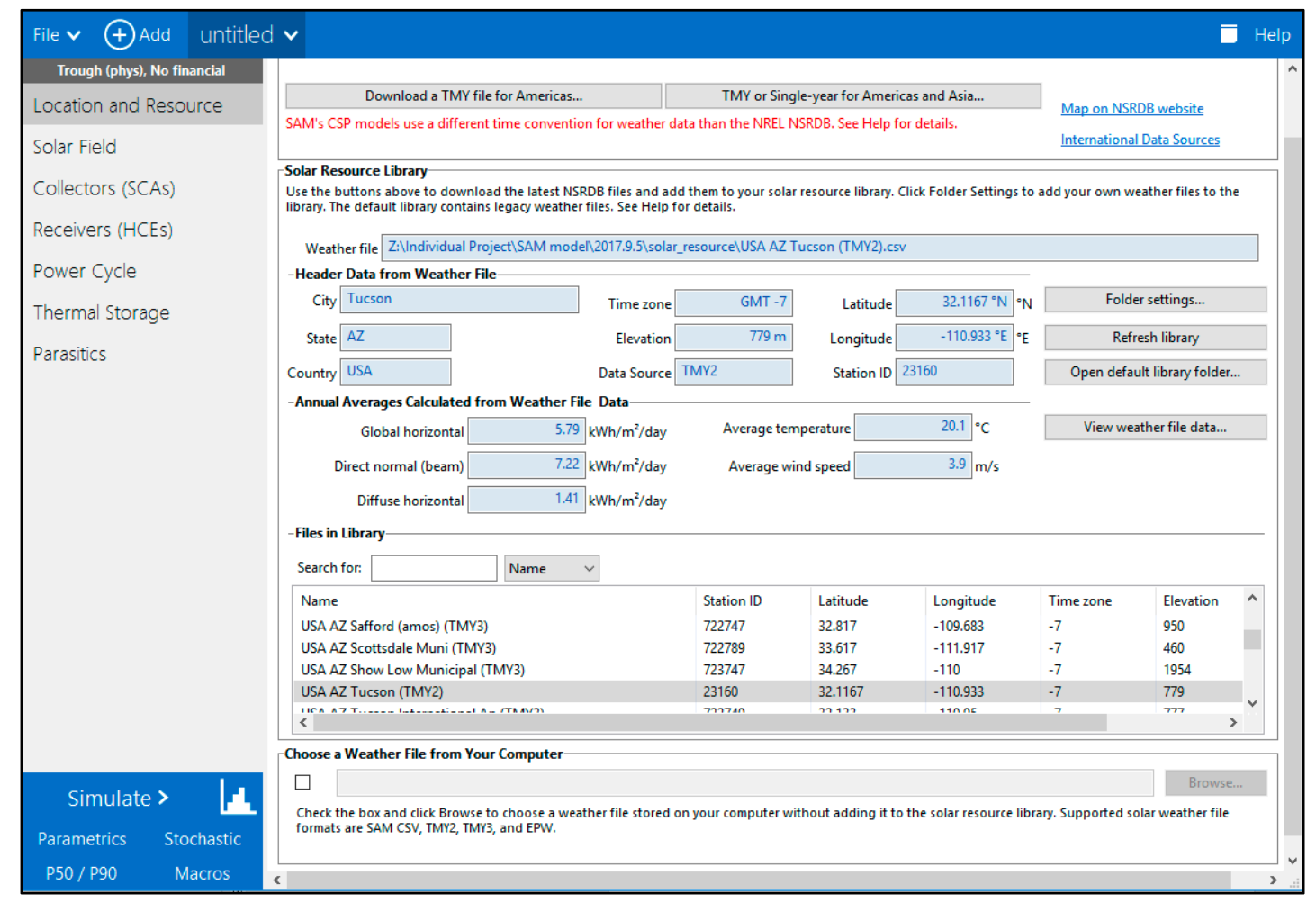

Figure 3. System Advisor Model (SAM) simulation software interface. 


\subsection{Estimation of The Project'S Total Costs}

The LCCA of CSP plants involves many calculations, most of which actually consist of basic arithmetic operations including addition, subtraction, multiplication, and division. These calculations must be built and presented sequentially and in a way where the end users can use the model very easily. Model maps are useful tools to visually depict the financial structure of a project as well as to simulate the effect of a change in a selected parameter or a set of parameters.

The initial investment cost (IIC) and annual costs (AC) are two important inputs for LCCA of an investment project or a technology development programme. IIC is the difference between the cash flow from investing activities in the initial investment year and the size of debt of the project. The financial model map for IIC of a CSP plant is represented in Figure 4. Denote by CFIA and SOD the cash flow from investing activities and the size of debt, respectively. Then,

$$
\mathrm{IIC}=\mathrm{CFIA}-\mathrm{SOD} .
$$

The value of cash flow from investing activities in the initial investment year is calculated by summing up the total purchase of property (TPP) and total reserve accounts (TRA). Therefore,

$$
\text { CFIA }=\text { TPP }+ \text { TRA } .
$$

The total purchase of property equals the sum of the total installed cost (TIC), debt closing cost (DCC), up-front fees (UFF) and construction financing (CFIN). The TIC is the amount of the project loan which depends on the plant size. The DCC and UFF are the payments related to the bank loan contracts. Therefore, the total purchase of property can be calculated by the following equation:

$$
\mathrm{TPP}=\mathrm{TIC}+\mathrm{DCC}+\mathrm{UFF}+\mathrm{CFIN} .
$$

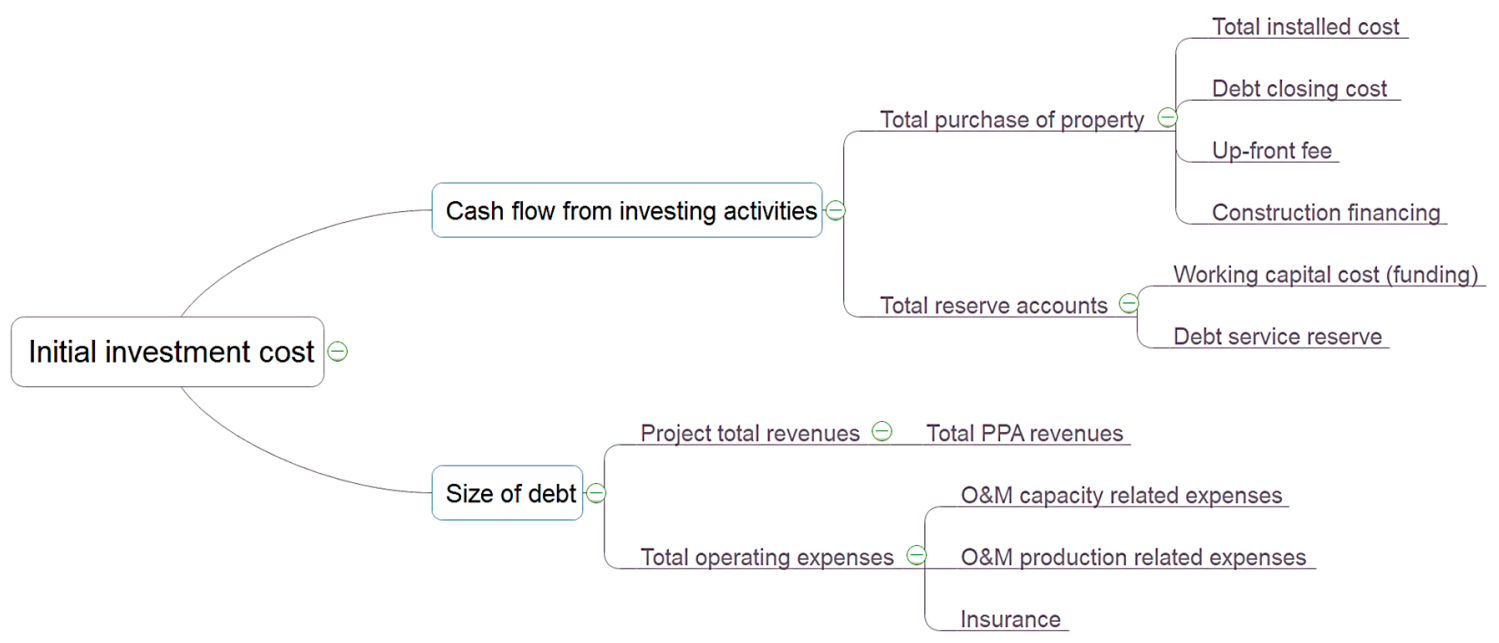

Figure 4. The financial map for initial investment cost of a CSP plant.

The amount of construction financing (CFIN) in Equation (9) is calculated by the following equation:

$$
\text { CFIN }=\text { Loan amount } \times \text { LIR , }
$$

where LIR is the loan interest rate. The total reserve accounts (TRA) in Equation (8) is calculated by summing the working capital cost (funding) and debt service reserve (DSR). Then,

$$
\text { TRA }=\text { WCC }+ \text { DSR, }
$$


where WCC is the working capital costs and DSR is the debt service reserve. The DSR is a fixed value for all operating years including the year of initial investment. WCC is calculated by multiplying the total operating expenses in a year by number of years of operation. Thus,

$$
\text { WCC }=\text { TOE } \times \text { Number of years of operation, }
$$

where TOE is the total operating expenses in a year, which is calculated by summing the O\&M capacity related expenses (OMCRE), O\&M production related expenses (OMPRE), and the insurance cost (I). Thus,

$$
\text { TOE }=\text { OMCRE }+ \text { OMPRE }+\mathrm{I},
$$

This value is subtracted from the project's total revenues to find the earnings before interest, taxes, depreciation, and amortization (EBITDA). Therefore,

$$
\text { EBITDA }=\text { PTR (PPA revenues) }- \text { TOE },
$$

where PTR is the project total revenues. EBITDA includes the cash available for debt services (CAFDS) over the project lifetime. This value is multiplied by the present value debt interest factor (PVDIF) to estimate the present debt value of CAFDS, i.e.,

$$
\text { Present debt value of CAFDS }=\text { CAFDS } \times \text { PVDIF } .
$$

By dividing the present debt value of CAFDS by the debt service coverage ratio (DSCR), the constant DSCR is calculated for all years. Thus,

$$
\text { Constant DSCR }=\text { Persent debt value of CAFDS } \div \text { DSCR }
$$

The size of debt (SOD) in Equation (7) equals the sum of constant DSCRs for all operating years throughout the project lifetime.

In order to estimate the annual costs, the financial model map in Figure 5 is used. The annual cost (AC) is calculated by summing total investment tax credit (ITC) in year one, tax benefit and liability (TB\&L) and interest on reserves (IOR), and subtracting the total operating expenses (TOE), principal payment (PP), debt interest payment (DIP), debt service reserve (DSR) and working capital reserve (WCR) (funding). Therefore:

$$
\mathrm{AC}=\mathrm{ITC}+\mathrm{TB} \& \mathrm{~L}+\mathrm{IOR}-\mathrm{TOE}-\mathrm{PP}-\mathrm{DIP}-\mathrm{DSR}-\mathrm{WCR} .
$$

The total investment tax credit (ITC) in Equation (17) is calculated by multiplying the ITC qualifying costs by ITC percentage. Thus,

$$
\text { ITC }(\text { year } 1)=\text { ITC qualifying cos ts } \times \text { ITC percentage }(\%) .
$$

The ITC qualifying cost is calculated by multiplying the total cash flow from investing activities (as presented in Equation (8)) by the loan interest rate (LIR), i.e.,

$$
\text { ITC qualifying costs }=\text { CFIA (at initial investment year }) \times \operatorname{LIR}(\%) \text {. }
$$

Referring to Equation (17), the tax benefit and liability (TB\&L) is calculated by multiplying taxable income (TI) and income tax rate (ITR). Thus,

$$
\mathrm{TB} \& \mathrm{~L}=\mathrm{TI} \times \operatorname{ITR}(\%),
$$


where the taxable income (TI) is the sum of EBITDA (calculated in Equation (14)) and the interest earned (IE), subtracted from the interest payment (IP) and tax depreciation (TD). Therefore,

$$
\mathrm{TI}=\mathrm{EBITDA}+\mathrm{IE}-\mathrm{IP}-\mathrm{TD},
$$

where IE is calculated from interest on reserves (IOR). IOR itself is calculated by multiplying the total reserve amount of the previous year by the interest on reserves rate (IORR). Thus,

$$
\mathrm{IOR}=\mathrm{TR}(\text { previous year }) \times \operatorname{IORR}(\%) .
$$

IP in Equation (21) is calculated by multiplying the size of debt (SOD) by annual interest rate (IR). Therefore,

$$
\mathrm{IP}=\mathrm{SOD} \times \mathrm{IR}(\%),
$$

The tax depreciation (TD) in Equation (21) is calculated based on the depreciation schedule amount for all operating years, which can be obtained from the SAM performance tool.

The principal payment (PP) in Equation (17) is calculated by subtracting the interest payment (calculated by Equation (23)) from the payments and interest (P\&I). Thus,

$$
\mathrm{PP}=\mathrm{P} \& \mathrm{I}-\mathrm{IP},
$$

where P\&I is calculated by dividing CAFDS by debt service coverage ratio (DSCR), i.e.,

$$
\mathrm{P} \& \mathrm{I}=\mathrm{CAFDS} \div \mathrm{DSCR} \text {. }
$$

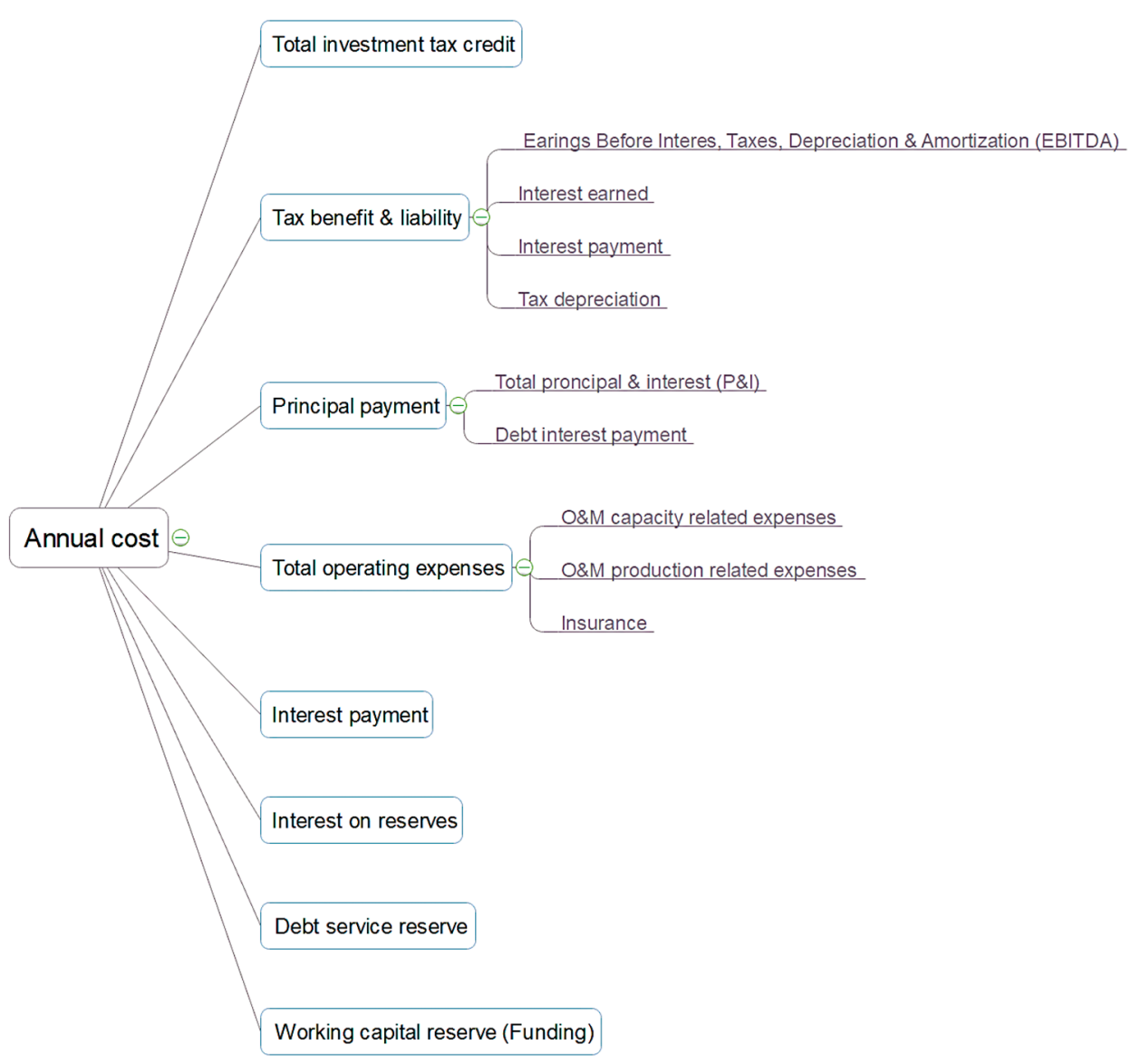

Figure 5. The financial model map for annual costs. 
The total operating expenses (TOE), debt interest payment (DIP), debt service reserve (DSR), and the working capital reserve (WCR) in Equation (17) are calculated in the same way as initial investment cost was calculated.

\subsection{Estimation of The Project's Annual Cash Flows}

In order to estimate the annual cash flows, the financial model map in Figure 6 is used. The annual cash flow (ACF) is calculated from the sum of total project returns (pre-tax) (TPR), tax benefit and liability (TB\&L), as well as total investment tax credit (ITC). Therefore,

$$
\mathrm{ACF}=\mathrm{TPR}(\text { Pre tax })+\mathrm{TB} \& \mathrm{~L}+\mathrm{ITC},
$$

The TPR is calculated by the following equation:

$$
\text { TPR }(\text { Pre tax })=\text { CFOA }- \text { CFIA }- \text { CFFA , }
$$

where CFOA is the cash flow from operating activities, CFIA is the cash flow from investing activities, and CFFA is the cash flow from financing activities.

The total cash flow from operating activities is calculated by the following equation:

$$
\mathrm{CFOA}=\mathrm{EBITDA}+\mathrm{IOR}-\mathrm{IP},
$$

where EBITDA, IOR and IP are calculated by Equations (14), (22) and (23), respectively.

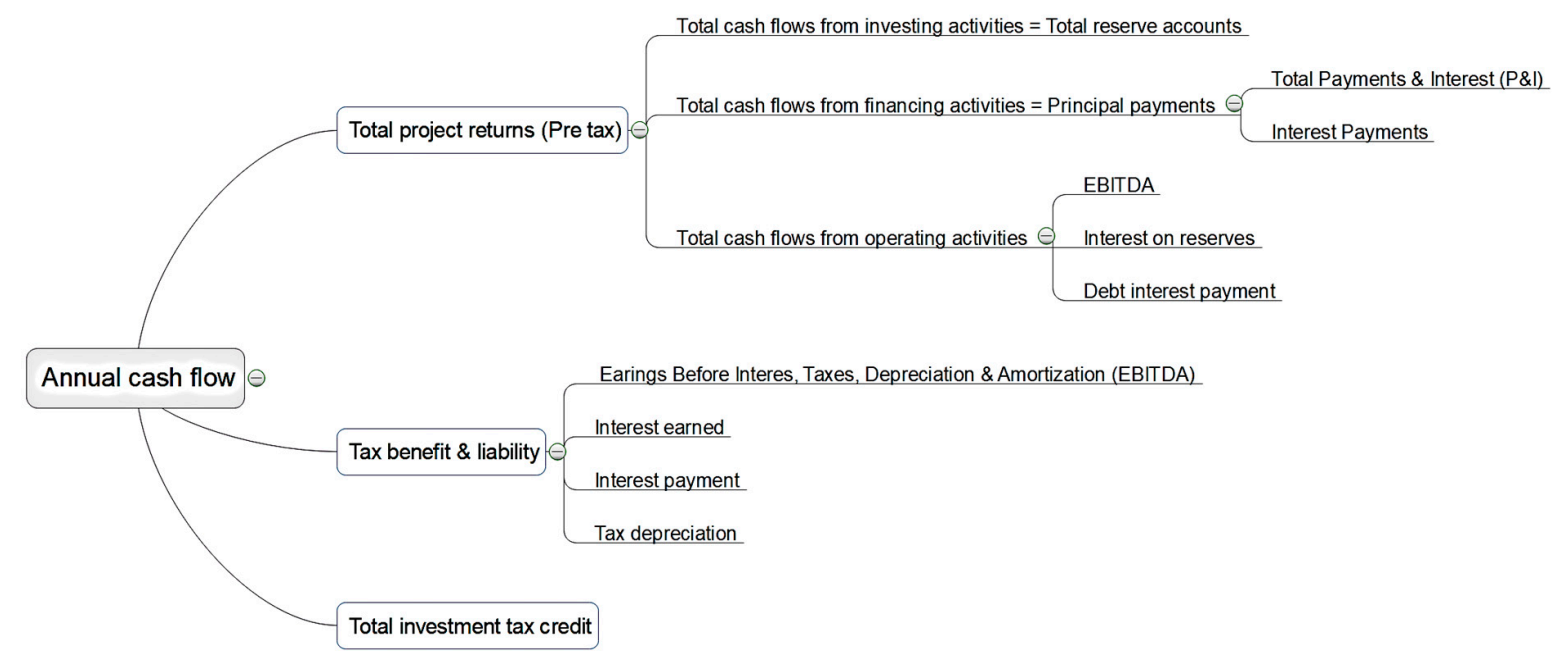

Figure 6. The financial model map for annual cash flows.

The total cash flow from investment activities is equal to total reserve accounts which were given by Equation (11) for each year. The total cash flow from financing activities equals the principal payment, which was calculated by Equation (24).

\subsection{Calculation of Output Metrics}

The output metrics of the model, including NPV, IRR, DPBP, CBR and LCoE are calculated using the Equations (1), (3), (4), (5) and (6), respectively.

\section{Case Study}

The city selected for our case study is Tucson, which is located in Arizona State in the USA. Tucson with over 530,000 citizens is the second most populated city in Arizona after Phoenix. The city is geographically situated in the middle of a desert named Sonoran (which is shared by the USA and 
Mexico) and is surrounded by mountain ranges. Historically, the city is a vital travel destination, an agricultural town center as well as a communication nexus [23]. Tucson city map is displaced in Figure 7.

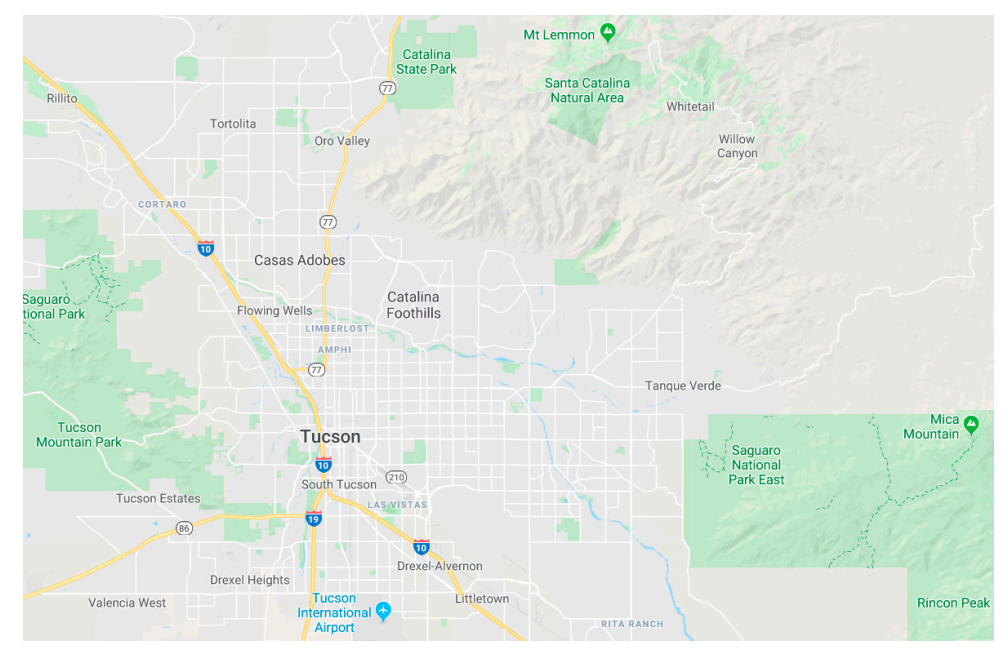

Figure 7. Tucson city map [24].

The solar energy development in Tucson city has been studied in the literature in the past few years (e.g. see $[25,26])$. These studies provide a good amount of information that is useful for feasibility analysis of a parabolic trough CSP plant in Tucson. In addition, some other information were collected from the field using a structured questionnaire. SAM's library file also provided useful information about the meteorological conditions of the city.

\subsection{Geography and Topography}

Tucson is situated about 115 miles southeast of the state capital, Phoenix. At the north, the city is joined with Santa Catalina and Tortolita mountains. To east and west, it is bordered by Rincon and Tucson mountains respectively. The city has the area of $587.2 \mathrm{~km}^{2}$, and it locates in an elevation of 2600 feet approximately above sea level which causes Tucson to have different weather conditions than cities nearby [27]. The Tucson geographical coordinates are 32.222 degree latitude, -110.926 degree longitude, and $753 \mathrm{~m}$ elevation. The topography within $3 \mathrm{~km}$ of Tucson contains only small variations in elevation, with a maximum elevation change of $43 \mathrm{~m}$ and an average elevation above sea level of $755 \mathrm{~m}[28]$.

\subsection{Weather Conditions and Temperature Variations}

In Tucson, the summers are hot, the winters are cold and dry, and it is mostly clear year round. Over the year, the temperature typically ranges from $5{ }^{\circ} \mathrm{C}$ to $39^{\circ} \mathrm{C}$ and is seldom below $0{ }^{\circ} \mathrm{C}$ or above $42{ }^{\circ} \mathrm{C}$ [28]. Figure 8 shows the temperature variations in Tucson city over the year.

The length of the day in Tucson alters significantly over the year. The shortest day is in December with 10 hours of daylight, and the longest day is in June with 14 hours of daylight [28]. Figure 9 shows the hours of daylight and twilight in Tucson city. 


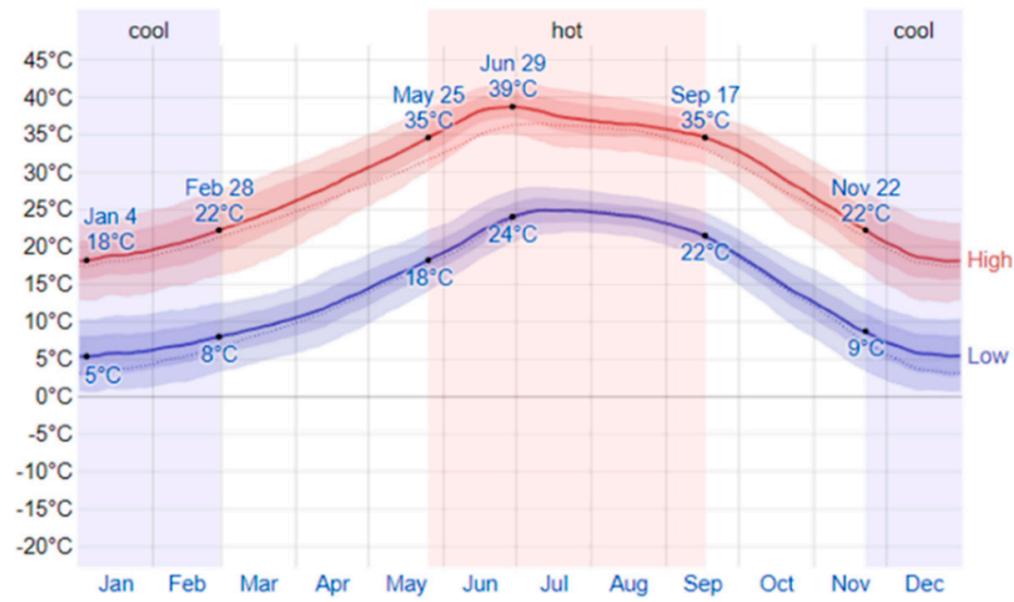

Figure 8. The variations of temperature in Tucson city over the year [21].

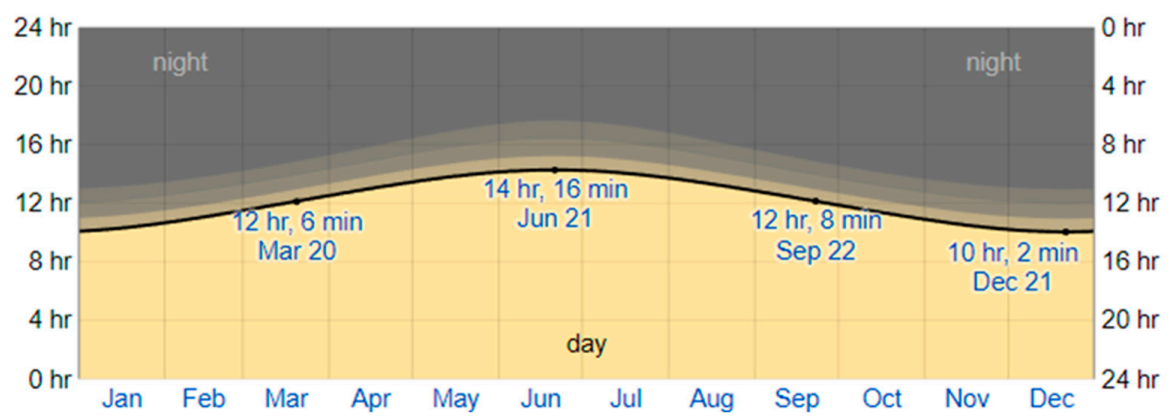

Figure 9. The hours of daylight and twilight in Tucson city over the year [26].

\subsection{Energy Supply and Price of Electricity}

There are several power plants generating electricity for residents in Tucson city. The heat sources used in these power plants vary from traditional fossil fuels (mainly natural gas) to renewables (mainly solar). Figure 10 depicts a map showing the location and type of power plants supplying the electricity of Tucson city.

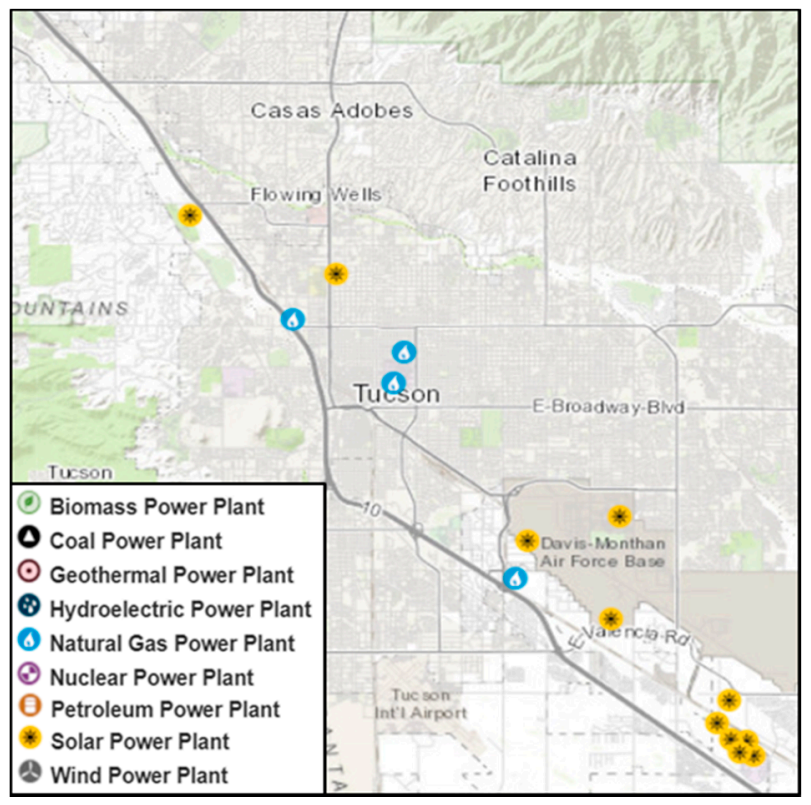

Figure 10. Power plants supplying the electricity of Tucson city [29]. 
Arizona is among the 20 states with the highest electricity price in the U.S. The commercial, residential and industrial electricity price rates in Tucson city are 11.26, 10.15 and $7.22 \mathrm{c} / \mathrm{kWh}$, respectively [30].

\subsection{Government's Attitude Toward Solar Power}

The American Recovery and Reinvestment Act (ARRA) in 2009 granted a package of incentives to encourage the solar energy sector [31]. In June 2013, the U.S. government placed forward a plan to cut the carbon pollution and reduce the impacts of climate change in America. As a support of this plan, the Department of Energy issued a loan guarantee solicitation for innovative renewable energy solutions as well as energy efficiency projects in the U.S. On June 2007, Tucson was designated by the Department of Energy as a Solar America City. In addition to receiving assistance through the Solar America Cities program, a significant investment has been made in solar energy by the local utility in Tucson city.

\subsection{Solar Energy Potential}

Tucson city has excellent solar resource for the development of both CSP and PV technologies. The average daily incident shortwave solar energy in Tucson experiences significant seasonal variation over the course of the year. The brightest time of the year lasts for around four months, from April to July, where the average daily incident shortwave energy per square meter $\left(\mathrm{m}^{2}\right)$ is above $7 \mathrm{kWh}$. The darkest time of the year lasts for about three months, from the beginning of November to January, where the average daily incident shortwave energy is below $4 \mathrm{kWh} / \mathrm{m}^{2}$ [28]. Figure 11 shows the average daily incident shortwave solar energy per $\mathrm{m}^{2}$ in Tucson city during a year.

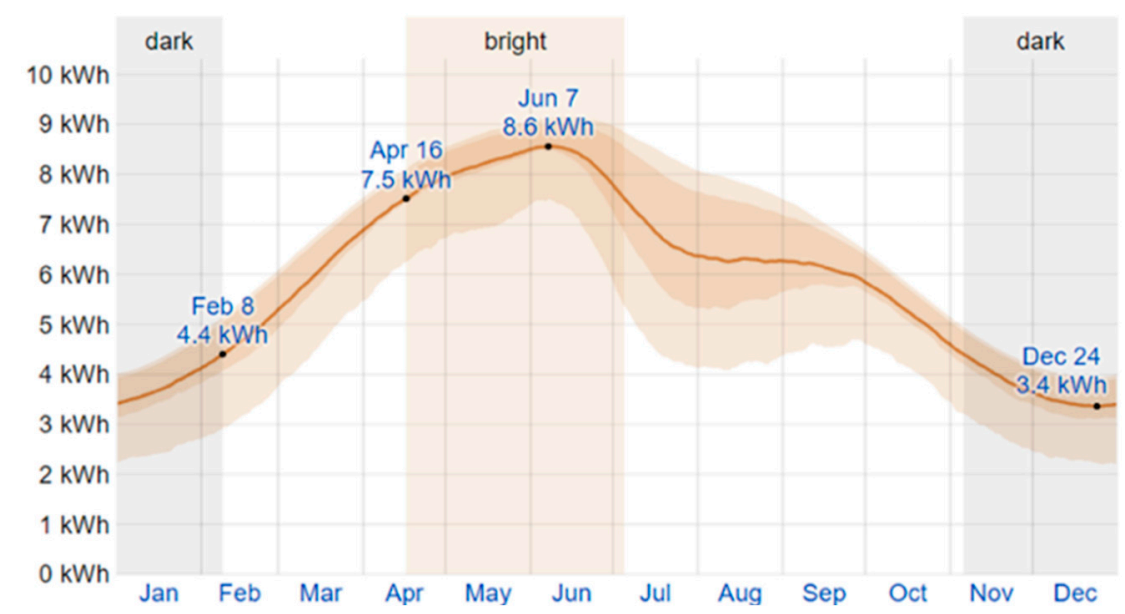

Figure 11. The average daily incident shortwave solar energy per square meter in Tucson city during a year.

\subsection{Input Data for SAM Simulations}

In order to run SAM simulations, the end-user needs to input all information that are required to calculate energy output from the CSP plant. Basically, SAM itself sets input assumptions by default when starting a new project file; however, the model users can change these default values to their specific values. After selecting the Tucson city from the built-in library, the weather data was fed as an input to the SAM. The SAM dataset contains detailed information about the city. These include: 
- Latitude (decimal degrees).

- Longitude (decimal degrees).

- Elevation above sea level (m).

- Hour of the day

- Diffuse horizontal radiation $\left(\mathrm{W} / \mathrm{m}^{2}\right)$

- Direct normal radiation $\left(\mathrm{W} / \mathrm{m}^{2}\right)$

- Global horizontal radiation $\left(\mathrm{W} / \mathrm{m}^{2}\right)$

- Albedo
- Atmospheric pressure (mbar)

- Dry bulb temperature $\left({ }^{\circ} \mathrm{C}\right)$

- Dew point temperature $\left({ }^{\circ} \mathrm{C}\right)$

- Wet bulb temperature $\left({ }^{\circ} \mathrm{C}\right)$

- Relative humidity (\%)

- Wind velocity $(\mathrm{m} / \mathrm{s})$

- Wind direction (degrees)

- Snow depth

The input data used for running the SAM simulations are given in Table 1.

Table 1. Input data for SAM simulation.

\begin{tabular}{|c|c|c|}
\hline No. & Input Description & Value \\
\hline 1 & Location & Tucson city, Arizona state, US \\
\hline 2 & Plant type & Parabolic trough \\
\hline 3 & Power rating of the plant & $50 \mathrm{MW}$ \\
\hline 4 & $\begin{array}{c}\text { Number of solar collector assemblies per } \\
\text { loop }\end{array}$ & 14 \\
\hline 5 & Collector type & Solargenix SGX-1 (SAM collector library) \\
\hline 6 & Receiver type & Schott PTR70 2008 (SAM receiver library) \\
\hline 7 & Field heat transfer fluid & Hitec Solar Salt \\
\hline 8 & Design loop outlet temp $\left(\mathrm{C}^{\circ}\right)$ & 550 \\
\hline 9 & Design gross output (MWe) & 167 \\
\hline 10 & Estimated gross to net conversion factor & $\begin{array}{c}90 \% \text {, where parasitic losses typically reduce net } \\
\text { output by this percentage of the design gross } \\
\text { power }\end{array}$ \\
\hline 11 & Condenser type & Air-cooled \\
\hline 12 & Full load hours of TES (hours) & 6 \\
\hline 13 & Parallel tank pairs & 2 \\
\hline 14 & Tank height (meters) & 15 \\
\hline 15 & Number of field subsections & 8 \\
\hline
\end{tabular}

\subsection{Input Data for Financial Calculations}

Though the majority of the data for Tucson city were available in SAM datasets, some additional information for calculation of the financial metrics were also required. These information were mainly obtained from the reports and regulations published by major governmental bodies in the U.S. as well as some local electricity suppliers based in Tucson, e.g. Tucson Electric Power (see [32]). Table 2 presents the input data used for the financial performance evaluation of a 50MW parabolic trough CSP plant in Tucson city.

Table 2. Input data for the CSP financial model.

\begin{tabular}{ccc}
\hline No. & Input Description & Value \\
\hline 1 & Annual energy output $(\mathrm{kWh})$ & $456,351,232$ (Derived from the SAM) \\
2 & Analysis period (years) & 25 \\
3 & Loan amount (Total installed cost) $(\$)$ & $794,177,280.00$ \\
4 & Loan interest rate $(\%)$ & 4 \\
5 & Inflation rate $(\%) /$ year & 2.5 \\
6 & Nominal discount rate $(\%) /$ year & 8.1375 \\
7 & Insurance rate $(\%) /$ year of installed cost & 0.5 \\
8 & Debt closing costs $(\$)$ & 450,000 \\
9 & PPA price (cent $/$ kWh) & 16 \\
10 & PPA price escalation $(\% /$ year) & 1 \\
11 & Tenor (years) & 18 \\
12 & Investment Tax credit (\%) & 30 \\
13 & Incentives & No incentives \\
14 & Time of delivery factor (TOD) & 1 for all periods \\
15 & Salvage value & 0 \\
\hline
\end{tabular}




\section{Results and Discussion}

After feeding all the input data, including annual energy output and financial parameters into the created Excel spreadsheet, the financial performance of the CSP project can be evaluated. In what follows, firstly, the financial metrics for a $50 \mathrm{MW}$ parabolic trough CSP plant in Tucson city are reported; secondly, the performance of the CSP investment is illustrated by some financial figures and charts; thirdly, a sensitivity analysis is performed and the results are discussed; and lastly, the model's validity will be analyzed.

\subsection{Financial Metrics}

Table 3 presents the financial metrics calculated for a 50MW parabolic trough CSP plant in Tucson city. As can be seen in the Table, the results show a positive NPV of over $\$ 64$ million. This means that the project's cash inflows are greater than cash outflows, and hence such investment will be economically viable. Nevertheless, a positive NPV will not always persuade the investors to invest in a project and some other financial metrics must also be considered to reach a robust investment decision.

Table 3. The financial metrics calculated for a 50MW parabolic trough CSP plant in Tucson city.

\begin{tabular}{cc}
\hline Financial Metric & Value \\
\hline Annual Energy Output (kWh) & $456,351,232$ \\
Net present value (NPV) $(\$)$ & $64,122,737.29$ \\
Internal rate of return (IRR) $(\%)$ & 12 \\
Discounted payback period (DPBP) (Years) & 17.24 \\
Benefit/Cost ratio (BCR) & 1.15 \\
Total life-cycle cost (TLCC) $(\$)$ & $773,304,457.05$ \\
LCoE (cent/kWh) & 16.06 \\
\hline
\end{tabular}

According to the results, the internal rate of return (IRR) of the investment was calculated as $12 \%$. This percentage is found very close to the average IRR value reported for parabolic trough CSP technologies in industry $(\sim 11.72 \%)$ [33]. The DPBP for CSP plants with parabolic trough technology is reported in the literature to be between 6.5 years and 17.6 years [33]. Our analysis shows that in the first quarter of year 17 of the project, the initial cost of the investment will be recovered.

The benefit cost ratio (BCR) of the project has been estimated as 1.15, which is greater than 1 . This means that the benefits of the project exceed its costs and hence, the investment in the CSP project is beneficial. The total life-cycle cost (TLCC) for 25 years was also estimated as $\$ 773,304,457.05$. TLCC can help investors choose the technology with the lowest cost, in particular in cases where different technology alternatives may have similar returns on investment or benefits.

The value of LCoE is estimated as 16.06 cents per $\mathrm{kWh}$. This value is desired to be as low as possible because it influences the price of electricity for the commercial, residential and industrial sectors. In our case study, this estimated value of $16.06 \mathrm{cent} / \mathrm{kWh}$ for LCoE is $10.7 \%$ lower than the global average LCoE for the CSP technology as reported by the International Renewable Energy Agency in 2018 [34].

\subsection{Financial Figures}

In this section, the performance of the CSP investment is illustrated by some financial figures and charts. For instance, Figure 12 shows the values of NPV of investment for 25 years of lifetime. In year zero, the negative NPV represents the initial cost of investment. Then after, when the plant begins operation the revenue streams increase over time and at the first quarter of year 17 the NPV reaches zero. After this point, the NPV becomes positive and the project will start generating profit. 


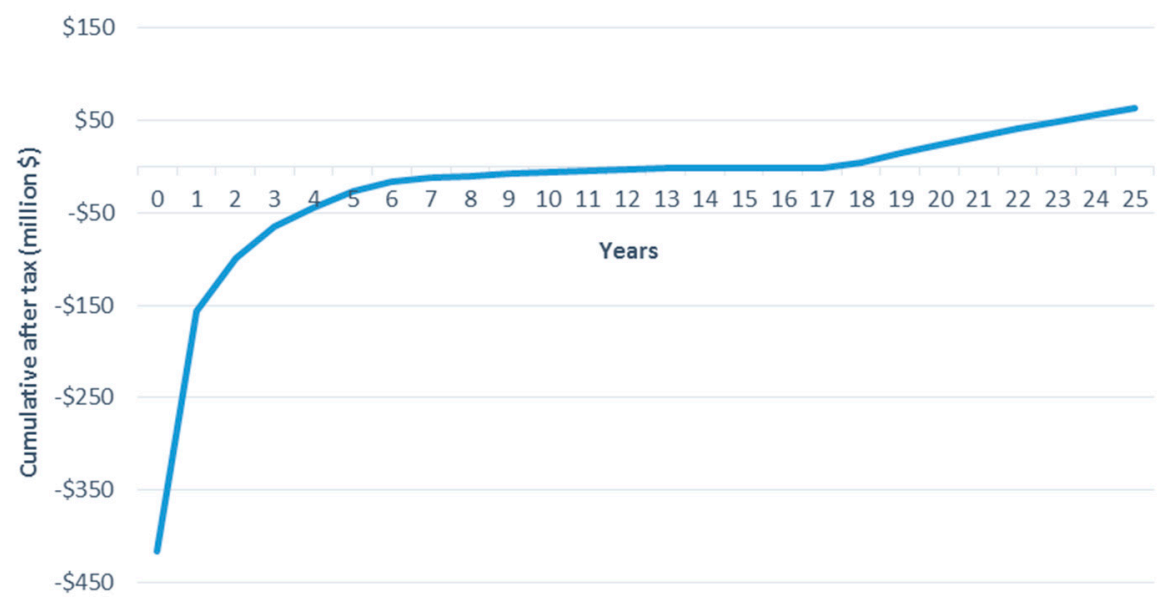

Figure 12. The annual net present value (NPV) during the project's lifetime period.

Figure 13 shows the annual revenue from the CSP investment during 25 years of project lifetime. As can be seen, the annual revenue trend shows an almost constant increase, referring to the yearly growth in PPA price which is $1 \%$. If the factor of time of delivery (TOD) in the financial analysis is assumed to change depending on the time period (peak or off-peak), the PPA price will then be influenced and thus the pattern of revenues will become different.

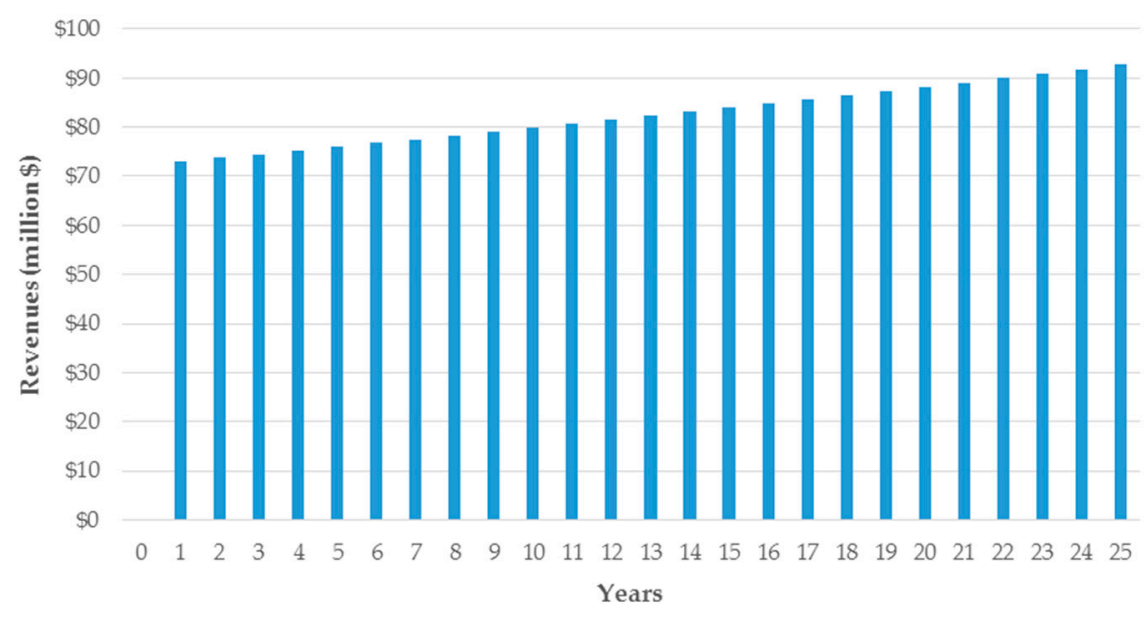

Figure 13. Annual revenues.

Figure 14 shows the trend of annual cash flow balance as well as cash flows of the project over 25 years. The significant amount of cash flow at the beginning of the project is because of the initial investment. In later years, the cash flow represents the returns from plant operation and debts payment. As a result, the trend decreases until year 17 when the initial cost is fully recovered. Additionally, when debts are entirely paid in year 18 , this increases the cash flow in the positive direction until the end of the project lifetime.

Figure 15 shows the annual cost of the project over 5 years. As can be seen, the initial cost before the CSP plant starts up is $\$ 416,749,292$. This initial investment was used partially for the first year expenses with a surplus remained for the next years. From year 2, the annual cost increases gradually until a maximum level at year 17 when the initial cost is recovered. After finishing the debts payment at year 18, the annual cost decreased. Then, a steady increase occurs between the years 19 and 24 . After that, the annual cost reduces again in the last year of the operation. 


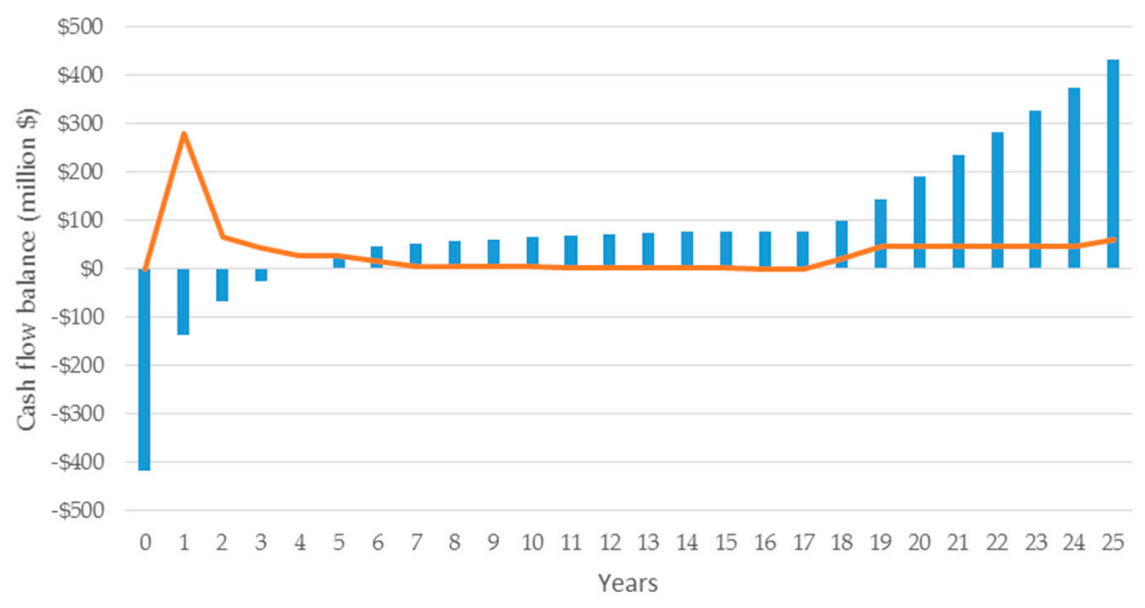

- Cash flow balance — Cash flow

Figure 14. Annual cash flow balance.

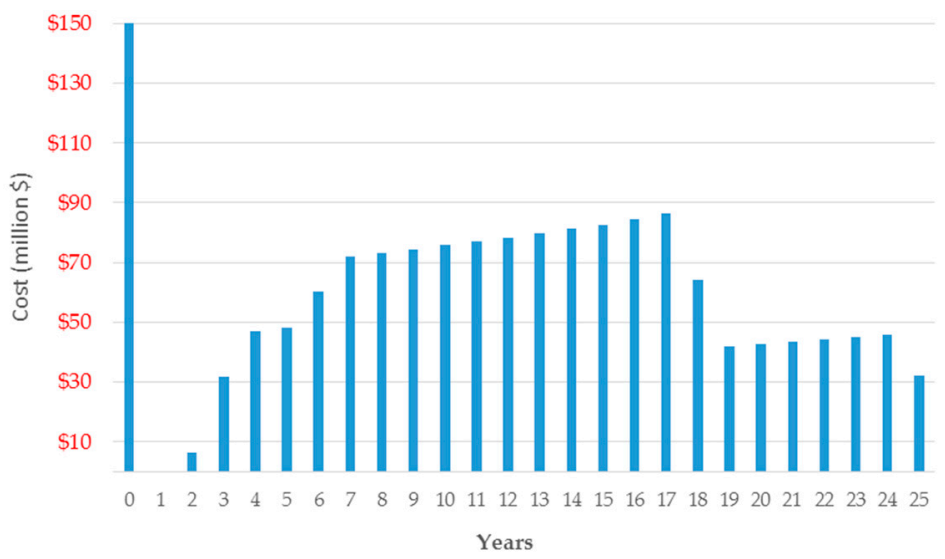

Figure 15. Annual cost.

\subsection{Sensitivity Analysis}

In this section, a sensitivity analysis is performed to identify those factors having the greatest impact on NPV, BCR and LCoE of the CSP plant. Among the input parameters, the energy production (derived from the SAM tool) and investment tax credit (ITC) were identified as the most influencing parameters. Figure 16 shows the effect of variations in energy production on NPV, BCR and LCoE. As shown, as the energy production increases, NPV and BCR will increase and LCoE will decrease. Our analysis shows that effect of DNI changes on NPV, BCR and LCoE is similar. The reason for this similarity is that, when DNI increases, the energy production of the CSP plant will also increase.

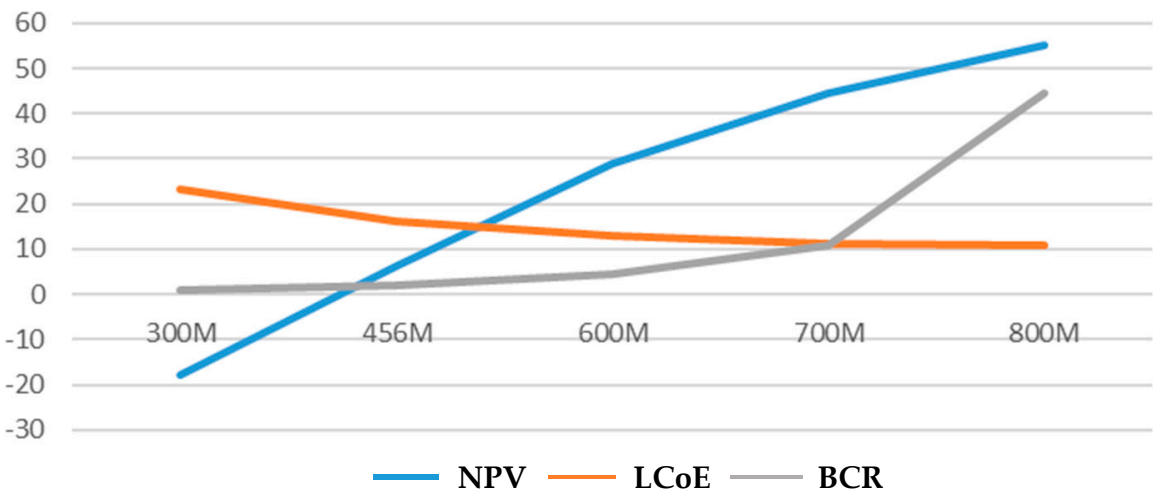

Figure 16. The effect of energy production $(\mathrm{kWh})$ on NPV, BCR and LCoE. 
Figure 17 shows the effect of variations in investment tax credit (\%) on NPV, BCR and LCoE. As can seen, unsurprisingly, the NPV and BCR increase while LCoE decreases with the increase in ITC rate.

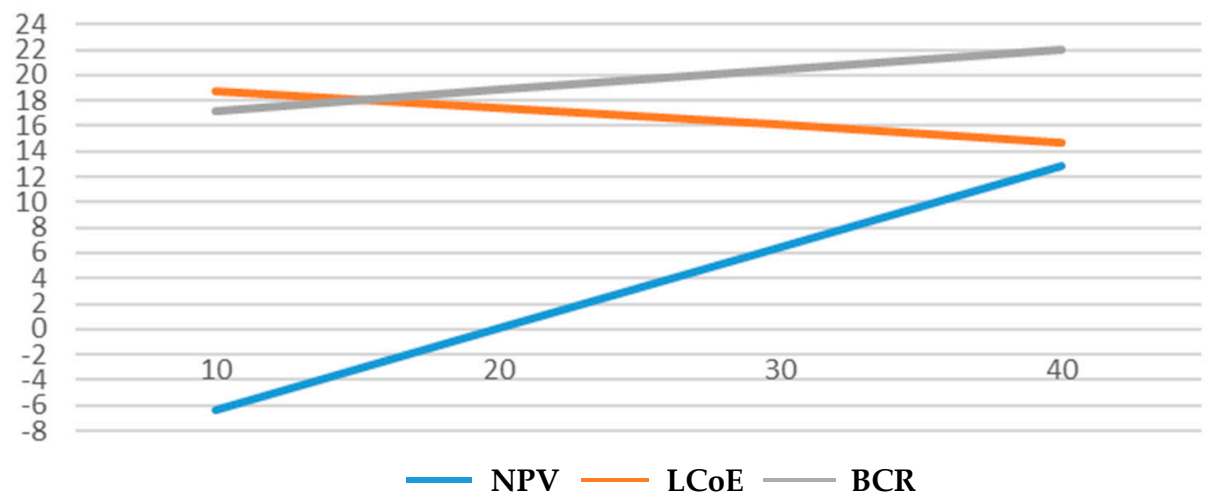

Figure 17. The effect of investment tax credit (\%) on NPV, benefit-cost ratio (BCR) and levelized cost of energy (LCoE).

\subsection{Model Validation}

In this section, the SAM financial tool is used to validate the proposed through-life cost analysis model for CSP projects. The same input data and financial parameters were fed into the SAM tool to make such comparison accurate. The financial metrics obtained from our through-life cost analysis model and the SAM financial tool are presented and compared with each other in Table 4.

Table 4. Financial model validation.

\begin{tabular}{cccc}
\hline Output Financial Metric & $\begin{array}{c}\text { The Created Financial Model } \\
\text { (Excel Spreadsheet) }\end{array}$ & SAM Tool & Difference (\%) \\
\hline Energy output $(\mathrm{kWh})$ & $456,351,232$ & $456,351,232$ & 0 \\
LCoE $(\$ \mathrm{kWh})$ & 0.16 & 0.16 & 0 \\
NPV $(\$)$ & $64,123,099.54$ & $64,192,692$ & $0.12 \%$ \\
IRR $(\%)$ & 12 & 10.28 & $16.7 \%$ \\
TLCC $(\$)$ & $\$ 773,304,457.05$ & $876,886,464$ & $11.8 \%$ \\
DPBP $($ year) & 17.24 & 20 & $13.8 \%$ \\
\hline
\end{tabular}

\section{Conclusions and Future Work}

In this paper, a through-life cost analysis model was presented to support the investment decision-making process in concentrated solar power (CSP) projects and technologies. The meteorological data of a particular location in the city of Tucson in Arizona State was collected and the NREL's SAM software tool was used to simulate the hourly power output. The direct normal irradiance (DNI) for the chosen location was $7.22 \mathrm{kWh} / \mathrm{m}^{2} /$ day and the energy output from a parabolic trough CSP power plant was estimated to be 456,351,232 kWh. The estimated energy output was then fed as an input parameter to a financial model, and the economic performance of the CSP project was calculated in terms of net present value (NPV), benefit-cost ratio (BCR), internal rate of return (IRR), discounted payback period (DPBP), and levelized cost of energy (LCoE). The financial calculations were performed using an excel spreadsheet which contains four modules, namely, input, calculations, output and charts, and sensitivity analysis. The analysis results showed a positive NPV of $\$ 64,123,099.54$ with an IRR of $12 \%$ and an average LCoE of $0.16 \$ / \mathrm{kWh}$. The investment had a DPBP of 17.25 years and the BCR was estimated to be 1.15 , with a total life-cycle cost (TLCC) of $\$ 773,304,457.05$.

A sensitivity analysis was also performed to identify the factors which have the most significant effect on the economic performance of CSP technologies. Our results showed that the values of NPV and BCR increase and the value of $\mathrm{LCOE}$ decreases with a rise in power output. The investment tax 
credit (ITC) showed also a similar impact on NPV, BCR, and LCoE. The rise in PPA price resulted in increased values of NPV and BCR and a slight increase in LCoE.

The developed Excel spreadsheet for cost analysis of a parabolic trough CSP technology is user-friendly and can accept any desired input and run all calculations to obtain the financial metrics. For future work, the model can be tested on other CSP technologies such as power tower, parabolic dish and LFRs. The model can also be extended by taking into account the social acceptance and the local environmental impacts of a CSP project. The social acceptance represents the local people's attitude toward the CSP technology compared to other power supply alternatives. The environmental impact represents how the CSP plant will reduce the environment impacts while meeting the energy demands.

Author Contributions: A.A. performed the analysis and wrote the initial manuscript text. M.S. supervised the work, provided technical advice for the research, made contributions to the paper's structure, revised the paper and responded to the comments from the referees. C.S., P.H. and A.E.-O. reviewed the manuscript and provided feedback on the manuscript. All authors have read and agreed to the published version of the manuscript.

Acknowledgments: The author would like to acknowledge the concentrated solar power plant managers and operators for providing data to carry out the research.

Conflicts of Interest: The authors declare no conflict of interest.

\section{References}

1. International Energy Agency (IEA). Renewables 2019: Analysis and Forecasts to 2024; OECD Publishing: Paris, France; Available online: https://webstore.iea.org/market-report-series-renewables-2019 (accessed on 6 January 2020).

2. Bhattarai, S.; Kafle, G.K.; Euh, S.-H.; Oh, J.-H.; Kim, D.H. Comparative study of photovoltaic and thermal solar systems with different storage capacities: Performance evaluation and economic analysis. Energy 2013, 61, 272-282. [CrossRef]

3. Chaanaoui, M.; Vaudreuil, S.; Bounahmidi, T. Benchmark of concentrating solar power plants: Historical, current and future technical and economic development. Procedia Comput. Sci. 2016, 83, 782-789. [CrossRef]

4. Mehta, A.; Kapoor, A.; Neopaney, H.K. Conceptual design of concentrated solar power plant using SPT-Solar power tower technology. In Proceedings of the International Symposium on Aspects of Mechanical Engineering and Technology for Industry, Itanagar, India, 6-8 December 2014; Volume 2.

5. Au, T.; Au, T.P. Engineering Economics for Capital Investment Analysis, 2nd ed.; Prentice-Hall, Inc.: Upper Saddle River, NJ, USA, 1992.

6. Shafiee, M.; Brennan, F.; Armada Espinosa, I. A parametric whole life cost model for offshore wind farms. Int. J. Life Cycle Assess. 2016, 21, 961-975. [CrossRef]

7. Ghosh, C.; Maiti, J.; Shafiee, M.; Kumaraswamy, K.G. Reduction of life cycle costs for a contemporary helicopter through improvement of reliability and maintainability parameters. Int. J. Qual. Reliab. Manag. 2018, 35, 545-567. [CrossRef]

8. Animah, I.; Shafiee, M.; Simms, N.; Erkoyuncu, J.A.; Maiti, J. Selection of the most suitable life extension strategy for ageing offshore assets using a life-cycle cost-benefit analysis approach. J. Qual. Maint. Eng. 2018, 24, 311-330. [CrossRef]

9. Dale, M. A comparative analysis of energy costs of photovoltaic, solar thermal, and wind electricity generation technologies. Appl. Sci. 2013, 3, 325-337. [CrossRef]

10. Mahlangu, N.; Thopil, G.A. Life cycle analysis of external costs of a parabolic trough Concentrated Solar Power plant. J. Clean. Prod. 2018, 195, 32-43. [CrossRef]

11. Zhao, Z.-Y.; Chen, Y.-L.; Thomson, J.D. Levelized cost of energy modeling for concentrated solar power projects: A China study. Energy 2017, 120, 117-127. [CrossRef]

12. Yang, S.; Zhu, X.; Guo, W. Cost-benefit analysis for the concentrated solar power in China. J. Electr. Comput. Eng. 2018, 4063691. [CrossRef]

13. Cogliani, E. The role of the direct normal irradiance (DNI) forecasting in the operation of solar concentrating plants. Energy Procedia 2014, 49, 1612-1621. [CrossRef]

14. Short, W.; Packey, D.; Holt, T. A Manual for the Economic Evaluation of Energy Efficiency and Renewable Energy Technologies; NREL/TP-462-5173; National Renewable Energy Laboratory (NREL): Golden, CO, USA, 2005. 
15. Kumar, R. Valuation: Theories and Cozncepts, 1st ed.; Academic Press: Cambridge, MA, USA, 2015; 514p.

16. Luo, J. Engineering, Financial and Net Energy Performance, and Risk Analysis for Parabolic Trough Solar Power Plants. Ph.D. Thesis, Texas A\&M University, College Station, TX, USA, 2014.

17. Babbei, D.F.; Merrill, C.B. Valuation of Interest-Sensitive Financial Instruments: SOA Monograph M-F196-1; Society of Actuaries: Schaumburg, IL, USA, 1996.

18. Zala, J.N.; Jain, P. Design and optimization of a biogas-solar-wind hybrid system for decentralized energy generation for rural India. Int. Res. J. Eng. Technol. 2017, 4, 649-656.

19. Pugh, P.G. Working top-down: Cost estimating before development begins. Proc. Inst. Mech. Eng. Part G 1992, 206, 143-151. [CrossRef]

20. Hooshmand, Y.; Köhler, P.; Korff-Krumm, A. Cost estimation in engineer-to-order manufacturing. Open Eng. 2016, 6, 22-34. [CrossRef]

21. Mendelsohn, M.; Kreycik, C.; Bird, L.; Schwabe, P.; Cory, K. The Impact of Financial Structure on the Cost of Solar Energy; NREL/TP-6A20-53086; National Renewable Energy Laboratory: Golden, CO, USA, 2012.

22. Dobos, A.; Neises, T.; Wagner, M. Advances in CSP simulation technology in the System Advisor Model. Energy Procedia 2014, 49, 2482-2489. [CrossRef]

23. City of Tucson. Available online: http://www.cityoftucson.org/ (accessed on 30 September 2018).

24. Google Maps. Available online: https://www.google.co.uk/maps (accessed on 30 September 2018).

25. Turchi, C. Parabolic trough Reference Plant for Cost Modeling with the Solar Advisor Model (SAM); Technical Report NREL/TP-550-47605; National Renewable Energy Lab.: Golden, CO, USA, 2010.

26. Bracken, N.; Macknick, J.; Tovar-Hastings, A.; Komor, P.; Gerritsen, M.; Mehta, S. Concentrating Solar Power and Water Issues in the U.S. Southwest; Technical Report NREL/TP-6A50-6137; National Renewable Energy Lab.: Golden, CO, USA, 2015.

27. Encyclopædia Britannica. 2018. Available online: https://www.britannica.com/place/Tucson (accessed on 19 August 2018).

28. The Typical Weather Anywhere on Earth, Weather Spark. Available online: https://weatherspark.com/ (accessed on 30 September 2018).

29. U.S. Energy Information Administration (EIA). Arizona-State Energy Profile Overview. 2018. Available online: https://www.eia.gov/state/?sid=AZ (accessed on 19 August 2018).

30. Electricity Local. Tucson, AZ Electricity Rates. 2018. Available online: https://www.electricitylocal.com/ states/arizona/tucson/. (accessed on 6 January 2020).

31. Pool, S.; Coggin, J.D.P. Fulfilling the promise of concentrating solar power. Center for American Progress. 2013. Available online: https://www.americanprogress.org/ (accessed on 6 January 2020).

32. Tucson Electric Power (TEP). Real-time Solar and Wind Generation. 2020. Available online: https: //www.tep.com/solar-dashboard/ (accessed on 6 January 2020).

33. Ren, L.Z.; Zhao, X.G.; Yu, X.X.; Zhang, Y.Z. Cost-benefit evolution for concentrated solar power in China. J. Clean. Prod. 2018, 190, 471-482.

34. International Renewable Energy Agency (IRENA). Renewable Energy Technologies: Cost Analysis Series, Concentrating Solar Power; IRENA Working Paper; IRENA: Abu Dhabi, UAE, 2012; Volume 1.

(C) 2020 by the authors. Licensee MDPI, Basel, Switzerland. This article is an open access article distributed under the terms and conditions of the Creative Commons Attribution (CC BY) license (http://creativecommons.org/licenses/by/4.0/). 